\title{
Use of vaccines in controlling bacteria fish diseases caused by Vibrio anuiliticus
}

\author{
Mohammed H. Bahnasawy ${ }^{1}$, Kadry A. M.El-Bakry ${ }^{1}$, Mohamed Kh.El-Safy ${ }^{2}$ and \\ Doaa.M.F.El-Borsh ${ }^{2}$ \\ 1- Zoology Department, Faculty of Science, Damietta University \\ 2- Department of fish disease and environment, Animal Health Research Institute.
}

\begin{abstract}
The present study was carried out to evaluate the effect of vaccination strategies to control vibriosis in farmed marine fish in Damietta governorate-Egypt. Two types of vaccines were papered including formalin-killed bacteria as well as heat killed whole cell bacterins as administrated by intraperitoneal injection sea bream fish. Fish immunized with formalin killed vaccine gave rise disease resistance better than heat killed vaccine in challenge test as denoted by relative level of protection (RLP). Determination of single immune diffusion, micro agglutination techniques and total protein content showed that formalin vaccine produce a good disease protection than the heat killed vaccine. Complete blood count examination for detecting lymphocytic count, hemoglobin \%, RBCs count and WBCs count showd that formalin vaccine was the best. The booster dose after three months declared elevation of immune status of the fish. Highly significant effect was observed in hemoglobin levels, circulating lymphocyte count and total protein content in fish immunized with formalin vaccine than heat killed vaccine
\end{abstract}

Key words: Sparus aurata, Vibrio alginoticus, Vibriosis, Vaccine, Vaccination, administration route.

\section{INTRODUCTION}

The aquacultures have grown rapidly over the last decades, and roof of this is the number of aquatic species, totaling to 600 , that are being farmed worldwide (FAO, 2016). The rapid expansion and intensification of aquaculture production has led to the outbreaks of new pathogens and infectious diseases caused by viruses, bacteria and parasites, inflicting major problems in the fish farming industry (Geng et al., 2012). The majority of bacterial diseases in aquaculture production systems are caused by some causative agents include bacteria from short, Gram-negative rods belonging to the families Enterobacteriaceae, Pseudomonadaceae (Pseudomonas) or Vibrionaceae (Vibrios). Typically, they cause septicaemic and ulcerative disease conditions. The long, Gram-negative, myxobacteria of the family Cytophagaceae, which are not recognized as pathogens of warm-blooded animals, may also cause heavy mortality in fish stocks (Barbosa et al., 2011). Bacteria are the most common among the pathogens in cultured fish that cause mass mortality in aquaculture both marine and fresh water (Mancuso, 2014). Vibrio species are gram -ve bacteria of the family Vibrionaceae. Vibriosis is a deadly haemorrhagic septicaemic disease affecting various marine and fresh/brackish water fish, bivalves and crustaceans causing severe economic losses worldwide (Frans et al., 2011).

Treatment of diseases has focused on chemicals and antibiotics. Treatment of affected fish with antibiotics is effective, but gives rise to problems such as accumulated resistance in the bacteria, which renders the antibiotic useless (Choi and Oh, 2007). Accumulation of antibiotic residues in fish tissue and environment cause human and animal health risk. Vaccination is an effective prophylactic treatment for infectious diseases in fish 
Mohammed H. Bahnasawy et al.

culture, but it may be very expensive and stressful to the fishes. A single vaccine is effective against only one specific type of pathogen, but limits the effectiveness for wide range of pathogens due to the complex antigenic structure (Ardo et al., 2008). The importance of vaccine development is associated with the prevention of diseases taking into account the triad of infection, were the interaction of the etiological agent, the host and the environmental conditions lead to the disease outbreak. Compared to terrestrial animals, controlling each one of these factors in aquaculture is almost impossible, water is the perfect vehicle for bacterial disease outbreak; therefore the vaccine preparation is specifically prepared for the affected site (Gudding, 2014).

Therefore, the main objective of the present study was to develop and compare the efficacies of various vaccine preparations against Vibriosis in silver sea bream. Also, to determine the potential protective mechanisms induced by each vaccination protocol. Moreover, to carry out field trails in vaccination and controlling of fish and detecting the efficacy of the prepared vaccines by Challenge test and estimating the Relative level of protection (RLP).

\section{MATERIALS AND METHODS Isolation and identification of vibrio species:}

Vibrio species was isolated from naturally diseases sea bass, sea bream, mullet and eel. The diseased fish suffered from petechial hemorrhage, detached scales, exophthalmia and abdominal dropsy. The pathological changes varied according to the stage of the disease where severe congestion of all internal organs with serous to sero-hemorrhagic fluid in the abdominal cavity was characteristic in some cases.

\section{Sampling and processing:}

One hundred (100) marine fishes of four different species were freshly captured from two localities in Egypt, (Manzala Lake, Shatta Village) through the different seasons of the year. On each season, twenty-five fish of each species were collected and freshly examined. For each fish clinical signs, average body weights and P.M examination were carried out using the methods described by (Buller, 2004). For bacterial isolation of vibrio species samples from gills, liver, spleen, kidney and external lesions from fishes were cultured on general and selective media.

\section{Culture media}

Media used for the isolation of the vibrio were:

\section{Liquid media}

Tryptic Soya broth (TSB) (Difco, Detroit, MI, USA) supplemented with $3 \%$ $\mathrm{NaCl}$ which was used for the growth of some suspected isolates prior to plating.

\section{Semi-Solid media}

$0.5 \%$ Nutrient agar medium (Oxoid, 1982) which is supplemented with $3 \% \mathrm{NaCl}$ which was used for the preservation of all isolated strains as well as for the detection of bacterial motility. Thiosulphate citrate bile salts sucrose agar (TCBS): (TCBS, Biolife, Milan, Italy) supplemented with $3 \% \mathrm{NaCl}$ which was used as selective medium for the isolation of Vibrio species (Whitman, 2004).

\section{Bacteriological examination:}

Postmortem (PM) examination: was carried according to (Conroy and Herman, 1981).

Identification of bacterial isolates: was carried out according to the methods described by Austin and Austin (1999).

Serotyping of two of the isolated vibrio anguilirium bacteria using TCBS media was carried out.

PCR was performed for detecting 2 virulent strains of Vibrio anguiliticus. 


\section{Use of vaccines in controlling bacteria fish diseases caused by Vibrio anuiliticus}

Experimental design: (vaccine preparation):

From the isolated vibrio anguiliticus serotyped and isolated on TCBS media the pure culture were taken in $500 \mathrm{ml}$ of $85 \%(\mathrm{Nacl})$ saline and washed three timed by centrifugation at $10 \mathrm{ppm}$, lastly the sediment of bacteria were taking for preparation of vaccine and store in refrigerator until the vaccine were papered. Formalin vaccine was prepared by addition $0.5 \%$ formalin overnight or heating at 65 ${ }^{\circ} \mathrm{C}$ for three hours, respectively. The prepared vaccines were stored in the refrigerator at $4{ }^{\circ} \mathrm{C}$ until the experimental technique was carried out. After washing the suspended bacteria, $500 \mathrm{ml}$ of suspended bacteria in formalin as well as $500 \mathrm{ml}$ of saline solution were used preparing the formalin-killed bacterins (FKC) and heat -killed bacterins (HKC), respectively.

Two kinds of whole cell bacterins, which were formalin-killed bacterins (FKC) and heat -killed bacterins (HKC), were prepared by treating the washed prepared bacterial suspension.

\section{Sterility test:}

The prepared vaccines were tested for sterility (completely inactivation of bacteria) by culturing on TCBS agar media and after incubation, no growth of colony was observed.

\section{Safety test:}

The prepared vaccine injected intraperitoneally in sea bream fish in two aquaria for formalin and heat killed vaccine and observed two weeks. The results were no changes in fish behavior or fish health.

\section{Experimental fish vaccination:-}

One hundred and seventy silver sea bream fishes, weighing approximately (50-100 g), were obtained from local fish farms in Damietta Governorate. Fish were transported to the laboratory and acclimated in Mediterranean seawater aquaria (20 L capacity) equipped with biological filtrates for three weeks prior to experiments. Fish, without any apparent infectious symptoms, were then randomly separated into experimental groups and maintained in aquaria ( $20 \mathrm{~L}$ capacity) equipped with seawater recirculation. Fish were fed with a pelleted diet purchased from commercials farms ( $25 \%$ protein) in ratio of 5\% (fish body weight/day) (Woo and Kelly, 1995). Throughout the experimental period, seawater temperature was kept at $20-22{ }^{\circ} \mathrm{C}$ and salinity was maintained constant at $33 \mathrm{ppm}$.

A total of 160 fished (sea bream) were divided in to four duplicated aquaria (20 fish each). The first duplicated groups of fish were injected intraperitoneal with formalin killed vaccine (FKV), while the second duplicated aquaria were injected intraperitoneal with heat killed vaccine (HKV). The third duplicated groups injected with formalin broth and saline only in the control groups, the forth groups fish only as control negative, respectively. All groups were injected i.p. with $0.2 \mathrm{ml} /$ fish for two months as initial dose and injected with booster dose after three months from the beginning of the vaccination process, respectively.

\section{Hematological examination:}

Fish under experimentation were anesthetized using lignocaine. Heparinized blood samples were collected from the caudal vein of vaccinated and control groups using sterile syringe. Serum samples were collected and stored at -20 ${ }^{\circ} \mathrm{C}$ until laboratory examination performed.

\section{The challenge infection:-}

A toxoid fresh $24 \mathrm{~h}$ bacterial culture colonies of a virulent ( $V$. alginolyticus) used for preparing a toxiod experimental challenge as described by (li et al., 2003). All fish were injected intraperitoneally with $0.2 \mathrm{~mL} /$ fish of $V$. 
Mohammed H. Bahnasawy et al.

alginolyticus at the dose of $5 \times 10^{5}$ CFU/fish. Fish mortality was monitored daily for two weeks. The survival rates and the protection (expressed as relative level of protection (RLP) of silver sea bream immunized with various vaccine preparations. Relative level of protection was evaluated according to the following formula described by (Amend, 1981). The efficacy of vaccines were performed by the following equation:

RLP $=(1-$ mortalities of vaccinated fish/mortalities of control fish) $\times 100$

\section{Serological experiments: The micro-agglutination test:}

Formalized whole culture vaccine was used as antigen in the serological tests according to Hay et al., (2002).

\section{Single immune diffusion test:}

From all vaccinated fish, heparinizedblood samples were collected. The formalized whole culture vaccine was used as antigen and the collected heparinized serum used as antibodies and the test subjected to the single immunodiffusion test, according to Ouchterloney (1962).

\section{Determination of Total plasma protein:}

Instrumentally, total protein concentration was determined in each sample according to Weicheselbaun (1946). Collected heparinized blood samples were used for determination of hemoglobin $(\mathrm{Hb} \%)$, total erythrocytic count (RBCs), total and differential leukocytic count (WBCs)

\section{The statistical analyses:}

The data collected were statistically analyzed using one-way ANOVA adapted by SAS (2000). Means were statistically compared for the significance $(\mathrm{P} \leq 0.05)$ using Duncan (1955) multiple range test.

\section{RESULTS AND DISCUSSION}

Regarding to the immunity status of vaccinated fish, determination of antibody titer was conducted by micro agglutination test and single immune diffusion was recorded in Tables ( $1 \& 2)$. The results detected by micro agglutination techniques (Table 1), two months later from the beginning of vaccination process indicated that the levels of the antibody titer were $(51.25 \mu \mathrm{l}$ $\pm 3.77)$ and $(45.83 \mu l \pm 3.59)$ in the vaccinated fish groups by formalin and heat killed vaccine, respectively. On the other hand, after three months the antibody titer were $(54.17 \mu 1 \pm 2.89)$ \& $(49.58 \mu 1$ \pm 3.34 ) in formalin and heat killed vaccine, respectively. Higher values of antibody titer was shown in formalin vaccinated fish than in fish vaccinated by heat killed vaccine whereas no changes in antibody titer in the fish of the control groups.

Concerning the results detected by single immune diffusion techniques, the formalized vaccine used in the vaccinated groups gave higher values $(1.13 \mathrm{~cm} \pm 0.08)$ $\&(1.16 \mathrm{~cm} \pm 0.07)$, respectively at two and three months duration after the vaccination process than that in the groups of fish vaccinated by heat killed vaccine which were $(1.05 \mathrm{~cm} \pm 0.11)$ and $((1.10 \mathrm{~cm}$ \pm 0.07 ), respectively (Table 2 ).

The current results showed significant higher values of immunological burden of fish groups vaccinated by formalized vaccine, than groups vaccinated by heat killed vaccine as illustrated in Tab1es $(1 \& 2)$. These were in agreement with those recorded by Jun $e t$ al. (2016) who reported elevations of serum agglutinating antibody titer in silver sea bream (Sparus sarba) vaccinated by formalized Vibrio. alginolyticus vaccine. Whereas results recorded by Colquhoun and Lillehaug (2014) showed high antibody titer by Formalin- or heat-killed whole cell vaccine.

The total levels of immunoglobulin after intraperitoneal injection showed significantly higher values $(\mathrm{P} \leq 0.05)$ in formalized and heat killed vaccine groups which were $(3.83 \mathrm{~g} / \mathrm{dl} \pm 0.08)$ and $(3.63$ $\mathrm{g} / \mathrm{dl} \pm 0.14$ ), respectively at two months 


\section{Use of vaccines in controlling bacteria fish diseases caused by Vibrio anuiliticus}

after vaccination as compared with the control groups which were $(2.70 \mathrm{~g} / \mathrm{dl}$ \pm 0.17 and $2.77 \mathrm{~g} / \mathrm{dl} \pm 0.08$ ) (Table $3 \&$ Fig. $3)$. This confirms the effect of vaccination as a factor influencing the immune response in the silver sea bream which may be attributing that the bacterins can stimulate the antibodies production in fish.

The levels of the total protein after three months from the beginning of vaccination process were $(4.15 \mathrm{~g} / \mathrm{dl} \pm 0.14)$ and $(3.78 \mathrm{~g} / \mathrm{dl} \pm 0.11)$, respectively in vaccinated fish groups by formalized and heat killed vaccine.

Regarding total protein, significant higher values of immunological status of fish groups vaccinated by formalized vaccine were detected than in groups vaccinated by heat killed vaccine as illustrated in (Table 3). The results of the present study were in agreement with results by $\mathrm{Hu}$ et al. (2012) where they reported that total protein increased in the vaccinated fish than in control fish during their research about the development and efficacy of an attenuated vibrio harveyi vaccine candidate with cross protective against vibrio algoliticus.

RBCs count at two and three months duration after the beginning of vaccination process in the experimental groups (formalin and heat killed vaccine) were significantly increased compared with control groups (Table 4 \& Fig.4). The results of the present study were in close contact with Bruno et al (2009) who recorded higher hematocrit values in vaccinated fish groups as well as number of erythrocytes and leukocytes than the non-vaccinated group. Intraperitoneal vaccination presented higher total number of leukocytes, lymphocytes and serum agglutination titer. In contrary our results were disagreed with that detected by Jun $e t$ al. (2016) who reported that no significant effect on the serum hematocrit and hemoglobin.

The present study showed that vaccination stimulates the haemopoesis and also induces the nonspecific immunity in fish. Similar results was given by Bailone et al. (2010) who showed that 10 days after immunization with a polyvalent vaccine at a concentration $1 \times 10^{8} \mathrm{CFU} / \mathrm{mL}$, there was an increase on erythrocytes, leukocytes, thrombocytes and circulating lymphocytes production.

With regard for vaccine, the hemoglobin concentration means values recorded in (Table $5 \&$ Fig. 5), were significantly $(\mathrm{P} \leq 0.05)$ increased compared with control groups at two and three months duration after the beginning of vaccination process in the experimental groups (formalin and heat killed vaccine). The results also revealed that hemoglobin concentration values were positively correlated with the RBCs count. Also, the present results were similar to Sajjad et al. (2012) who recorded that hemoglobin was elevated significantly, especially in the fish immunized by the formalin- and phenolkilled bacterins through various administration routes. On the other hand, the current results were disagreed with that detected by Jun et al. (2016) who reported that there was no significant effect on the serum hematocrit and hemoglobin.

Concerning the results recorded in (tab.6 and fig .6) clarify that there were significant increases $(\mathrm{P} \leq 0.05)$ in total and differential leukocytic counts at two and three months after vaccination in the experimental groups (formalin and heat killed vaccine) compared with control groups.

Significant higher total leukocytic counts values of immunological status of fish groups vaccinated by formalized vaccine, than that vaccinated by heat killed vaccine as illustrated in Table (7). These results are in agreement with the results of Salah et al. (2015) who recorded that the lymphocytes were significantly increased in vaccinated fish in comparison with unvaccinated group at all periods. Similar studies showed that 10 days after immunization with a polyvalent vaccine at a concentration $1 \times 10^{8} \mathrm{CFU} / \mathrm{mL}$, there was an increase leukocytes, thrombocytes and 
Mohammed H. Bahnasawy et al.

circulating lymphocytes production (Bailone et al., 2010). On the other hand, Aly et al .2000) reported a marked increase in the number of lymphocytes around the activated melanomacrophage centers in the kidney together with a maximal splenic response in the form of activated melanomacrophage centers with marked increase in macrophages and lymphocytes together with proliferation of hematopoietic elements around the splenic sinuses. Diaz et al. (2006) reported that high lymphocytic ability in gilthead sea bream (S. aurata L.) specimens given a mixture of two inactivated bacteria.

It was clear from results in Table (8) that relative level of protection (R.L.P) at the end of the experiment of the vaccinated sea bream fish groups by formalin vaccine was 91.66 , while it was 83.33 in vaccinated fish groups produced by heat killed vaccine. Higher values of RLP showed in formalin vaccinated fish than in fish vaccinated by heat killed vaccine whereas the levels of RLP in the fish of the control groups were 16.66 and zero in control -ve and control +ve, respectively. The results of the RLP confirm the role of the humeral antibodies in protecting fish against Vibrio. Alginolyticus infection.

These results agree with that obtained by Jun et al. (2016) who found that the i.p. delivery route, fish immunized with formalin killed acquired the best protection, whereas the other vaccine preparations gave variable protective effects upon pathogenic $V$. alginolytics challenges.

\section{Conclusion:}

The present results indicated that formalin- or heat killed whole cell bacteria are currently the most popular vaccines employed in farmed fish, and good protection against vibriosis, however, formalin gives the best results..

Table (1): Antibody titer of fish after two and three months of vaccination.

\begin{tabular}{|c|c|c|c|c|}
\hline \multirow{2}{*}{ Vaccination } & Two months & Three months & \multicolumn{2}{|c|}{ T-test } \\
\cline { 2 - 5 } & Mean \pm SD & Mean \pm SD & T-test & P-value \\
\hline $\begin{array}{c}\text { Control-ve } \\
(\mathrm{N}=12)\end{array}$ & $0.00 \pm 0.00$ & $0.00 \pm 0.00$ & - & - \\
\hline $\begin{array}{c}\text { Control+ve } \\
(\mathrm{N}=12)\end{array}$ & $0.00 \pm 0.00$ & $0.00 \pm 0.00$ & - & - \\
\hline $\begin{array}{c}\text { Heat killed } \\
(\mathrm{N}=12)\end{array}$ & $45.83 \pm 3.59$ & $49.58 \pm 3.34$ & 2.46 & $0.032 *$ \\
\hline $\begin{array}{c}\text { Formalized } \\
(\mathrm{N}=12)\end{array}$ & $51.25 \pm 3.77$ & $54.17 \pm 2.89$ & 3.02 & $0.012 *$ \\
\hline
\end{tabular}

*extremely significant.

Data in each Colum represented the mean \pm standard deviation.

-ve control: fish only +ve control: fish injected with formalin. 
Use of vaccines in controlling bacteria fish diseases caused by Vibrio anuiliticus

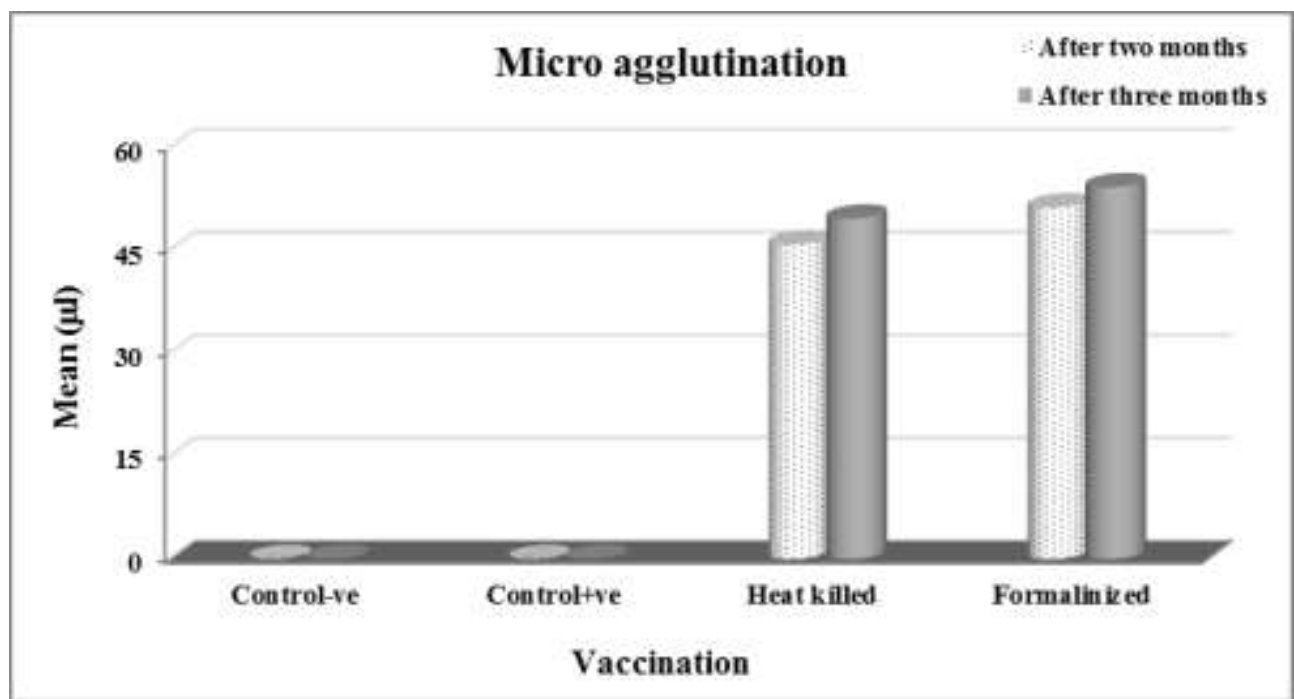

Fig. (1): Antibody titer of fish after two and three months of vaccination.

Table (2): Antibody titer after two and three months of vaccination.

\begin{tabular}{|c|c|c|c|c||}
\hline \multirow{2}{*}{ Vaccination } & Two months & Three months & \multicolumn{2}{|c|}{ T-test } \\
\cline { 2 - 5 } & Mean \pm SD & Mean \pm SD & T-test & P-value \\
\hline $\begin{array}{c}\text { Control-ve } \\
(\mathrm{N}=12)\end{array}$ & $0.00 \pm 0.00$ & $0.00 \pm 0.00$ & - & - \\
\hline $\begin{array}{c}\text { Control+ve } \\
(\mathrm{N}=12)\end{array}$ & $0.00 \pm 0.00$ & $0.00 \pm 0.00$ & - & - \\
\hline $\begin{array}{c}\text { Heat killed } \\
(\mathrm{N}=12)\end{array}$ & $1.05 \pm 0.11$ & $1.10 \pm 0.07$ & 1.20 & 0.256 \\
\hline $\begin{array}{c}\text { Formalized } \\
(\mathrm{N}=12)\end{array}$ & $1.13 \pm 0.08$ & $1.16 \pm 0.07$ & 1.48 & 0.166 \\
\hline
\end{tabular}

Data in each Colum represented the mean \pm standard deviation. -ve control: fish only +ve control: fish injected with formalin.

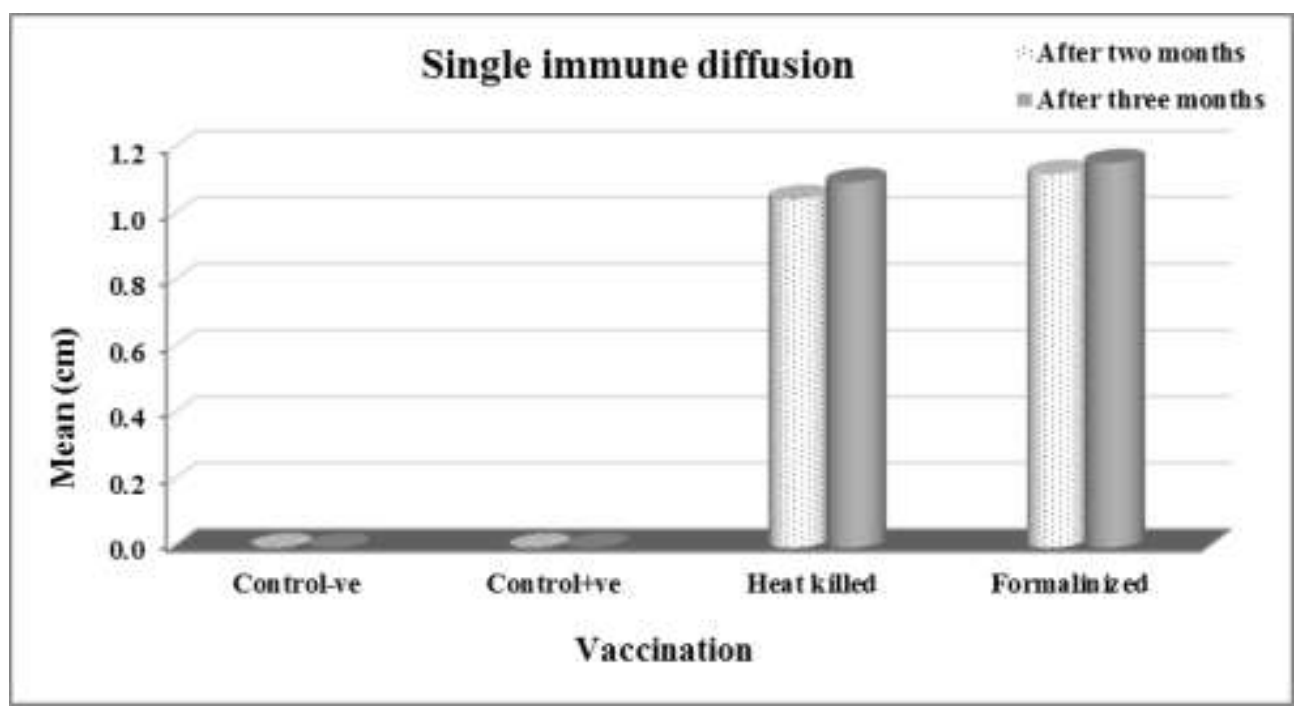

Fig. (2): Antibody titer after two and three months of vaccination. 
Mohammed H. Bahnasawy et al.

Table (3): Total protein in vaccinated fish after two and three months of vaccination.

\begin{tabular}{|c|c|c|c|c||}
\hline \multirow{2}{*}{ Vaccination } & Two months & Three months & \multicolumn{2}{|c|}{ T-test } \\
\cline { 2 - 5 } & Mean \pm SD & Mean \pm SD & T-test & P-value \\
\hline $\begin{array}{c}\text { Control-ve } \\
(\mathrm{N}=12)\end{array}$ & $2.70 \pm 0.17$ & $2.72 \pm 0.14$ & 0.26 & 0.799 \\
\hline $\begin{array}{c}\text { Control+ve } \\
(\mathrm{N}=12)\end{array}$ & $2.77 \pm 0.08$ & $2.77 \pm 0.08$ & - & - \\
\hline $\begin{array}{c}\text { Heat killed } \\
(\mathrm{N}=12)\end{array}$ & $3.63 \pm 0.14$ & $3.78 \pm 0.11$ & 4.78 & $0.001^{* * *}$ \\
\hline $\begin{array}{c}\text { Formalized } \\
(\mathrm{N}=12)\end{array}$ & $3.83 \pm 0.08$ & $4.15 \pm 0.14$ & 6.92 & $0.001^{* * *}$ \\
\hline
\end{tabular}

*extremely significant.

Data in each Colum represented the mean \pm standard deviation.

-ve control: fish only +ve control: fish injected with formalin

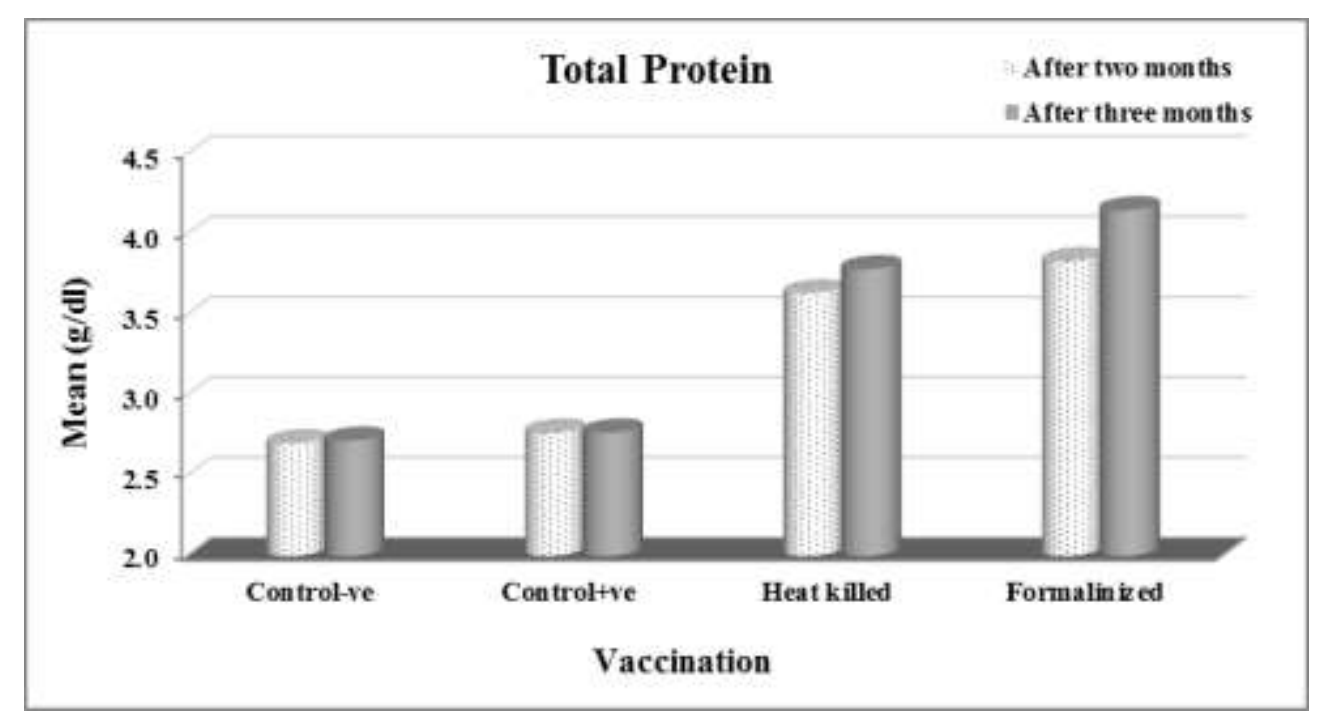

Fig. (3): Total protein in vaccinated fish after two and three months of vaccination.

Table (4): RBCs $\left(10^{6} / \mathrm{dl}\right)$ in vaccinated fish after two and three months of vaccination.

\begin{tabular}{|c|c|c|c|c|}
\hline \multirow{2}{*}{ Vaccination } & Two months & Three months & \multicolumn{2}{|c|}{ T-test } \\
\cline { 2 - 5 } & Mean \pm SD & Mean \pm SD & T-test & P-value \\
\hline $\begin{array}{c}\text { Control-ve } \\
(\mathrm{N}=12)\end{array}$ & $1.38 \pm 0.07$ & $1.41 \pm 0.04$ & 1.15 & 0.273 \\
\hline $\begin{array}{c}\text { Control+ve } \\
(\mathrm{N}=12)\end{array}$ & $1.39 \pm 0.06$ & $1.40 \pm 0.07$ & 0.56 & 0.585 \\
\hline $\begin{array}{c}\text { Heat killed } \\
(\mathrm{N}=12)\end{array}$ & $2.13 \pm 0.05$ & $2.35 \pm 0.02$ & 13.72 & $0.001 * * *$ \\
\hline $\begin{array}{c}\text { Formalized } \\
(\mathrm{N}=12)\end{array}$ & $2.32 \pm 0.01$ & $2.41 \pm 0.03$ & 10.06 & $0.001 * * *$ \\
\hline
\end{tabular}

*extremely significant.

Data in each Colum represented the mean \pm standard deviation.

-ve control: fish only +ve control: fish injected with formalin. 


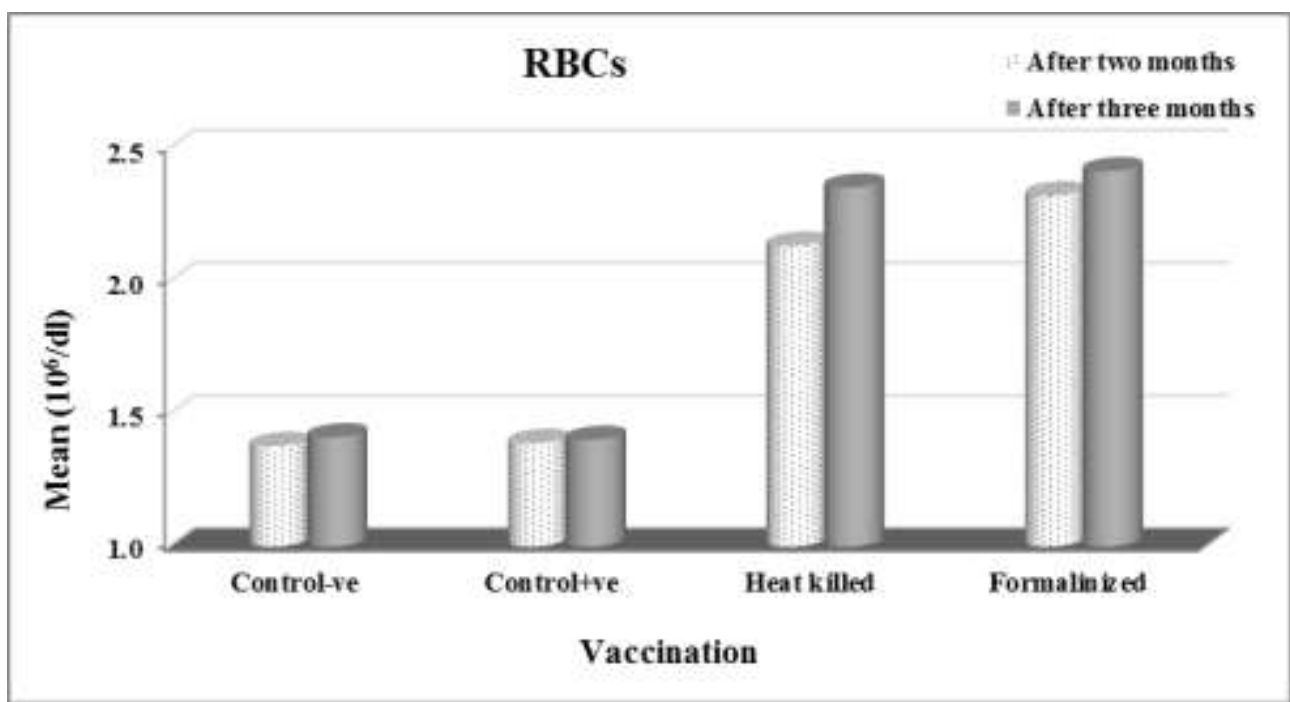

Fig. (4): RBCs in vaccinated fish after two and three months of vaccination.

Table (5): Haemoglobin in vaccinated fish after two and three months of vaccination.

\begin{tabular}{||c|c|c|c|c||}
\hline \multirow{2}{*}{ Vaccination } & Two months & Three months & \multicolumn{2}{|c|}{ T-test } \\
\cline { 2 - 6 } & Mean \pm SD & Mean \pm SD & T-test & P-value \\
\hline $\begin{array}{c}\text { Control-ve } \\
(\mathrm{N}=12)\end{array}$ & $7.03 \pm 0.39$ & $6.99 \pm 0.43$ & 0.19 & 0.855 \\
\hline $\begin{array}{c}\text { Control+ve } \\
(\mathrm{N}=12)\end{array}$ & $7.00 \pm 0.49$ & $7.08 \pm 0.55$ & 0.44 & 0.665 \\
\hline $\begin{array}{c}\text { Heat killed } \\
(\mathrm{N}=12)\end{array}$ & $8.51 \pm 0.27$ & $9.48 \pm 0.24$ & 7.69 & $0.001^{* * *}$ \\
\hline $\begin{array}{c}\text { Formalized } \\
(\mathrm{N}=12)\end{array}$ & $9.39 \pm 0.41$ & $10.33 \pm 0.36$ & 8.87 & $0.001^{* * *}$ \\
\hline
\end{tabular}

*extremely significant.

Data in each Colum represented the mean \pm standard deviation.

-ve control: fish only +ve control: fish injected with formalin.

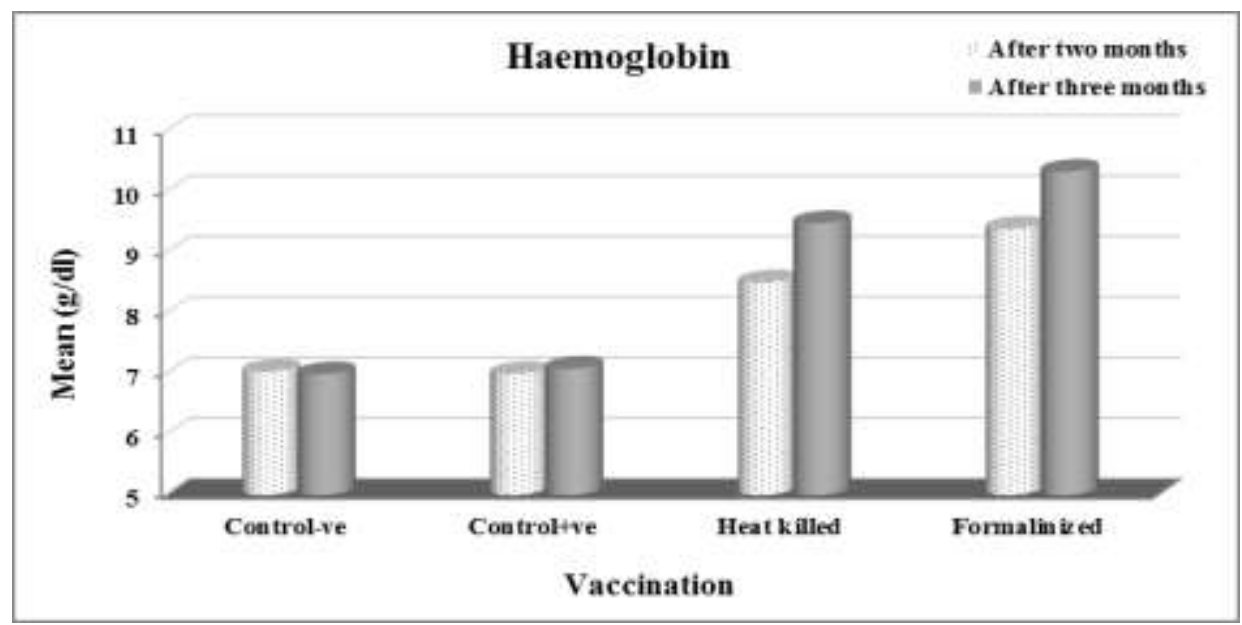

Fig. (5): Hemoglobin in vaccinated fish after two and three months of vaccination. 
Mohammed H. Bahnasawy et al.

Table (6): WBCs $\left(10^{3} / \mathrm{dl}\right)$ in vaccinated fish after two and three months of vaccination.

\begin{tabular}{|c|c|c|c|c||}
\hline \multirow{2}{*}{ Vaccination } & Two months & Three months & \multicolumn{2}{|c|}{ T-test } \\
\cline { 2 - 6 } & Mean \pm SD & Mean \pm SD & T-test & P-value \\
\hline $\begin{array}{c}\text { Control-ve } \\
(\mathrm{N}=12)\end{array}$ & $51.52 \pm 1.94$ & $51.95 \pm 2.16$ & 0.54 & 0.597 \\
\hline $\begin{array}{c}\text { Control+ve } \\
(\mathrm{N}=12)\end{array}$ & $49.88 \pm 1.83$ & $51.61 \pm 2.53$ & 1.61 & 0.137 \\
\hline $\begin{array}{c}\text { Heat killed } \\
(\mathrm{N}=12)\end{array}$ & $85.38 \pm 1.59$ & $88.31 \pm 1.36$ & 5.78 & $0.001 * * *$ \\
\hline $\begin{array}{c}\text { Formalized } \\
(\mathrm{N}=12)\end{array}$ & $90.29 \pm 1.34$ & $95.34 \pm 2.19$ & 9.55 & $0.001 * * *$ \\
\hline
\end{tabular}

*extremely significant.

Data in each Colum represented the mean \pm standard deviation.

-ve control: fish only +ve control: fish injected with formalin.

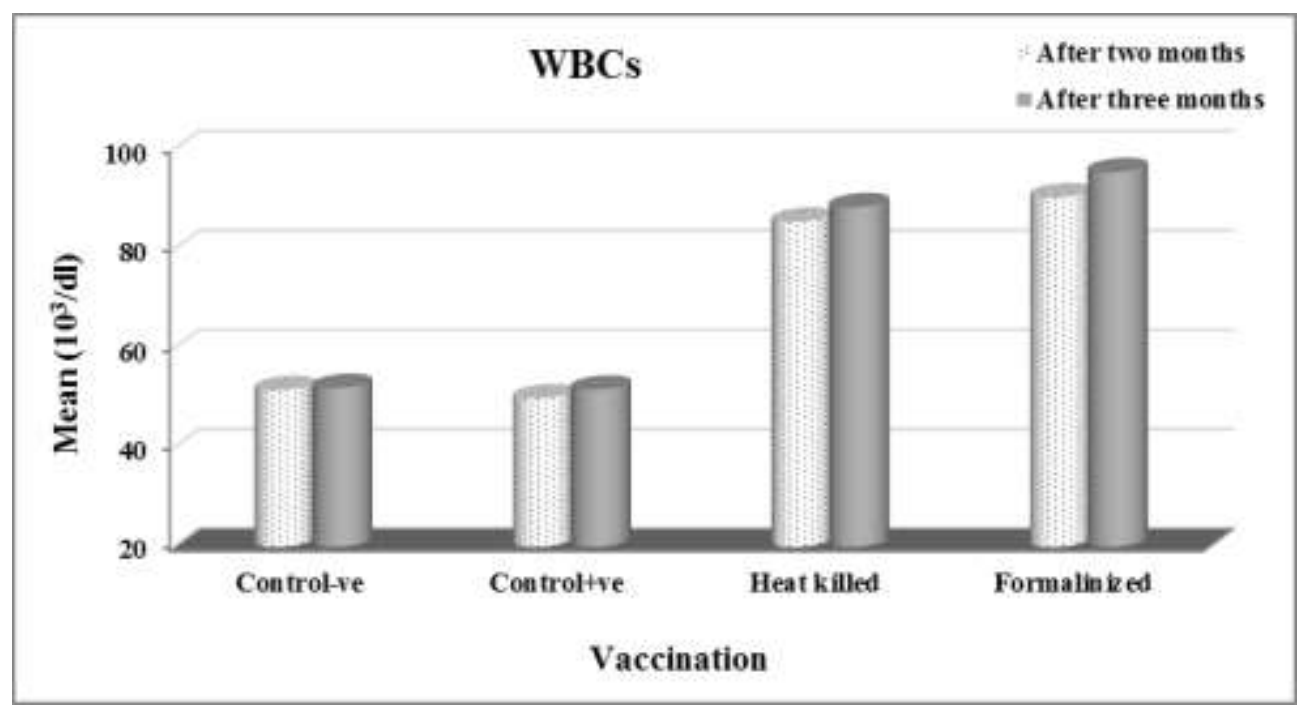

Fig. (6): WBCs in vaccinated fish after two and three months of vaccination.

Table (7): Lymphocytes in vaccinated fish after two and three months of vaccination.

\begin{tabular}{|c|c|c|c|c||}
\hline \multirow{2}{*}{ Vaccination } & Two months & Three months & \multicolumn{2}{|c|}{ T-test } \\
\cline { 2 - 5 } & Mean \pm SD & Mean \pm SD & T-test & P-value \\
\hline $\begin{array}{c}\text { Control-ve } \\
\mathrm{N}=12\end{array}$ & $52.33 \pm 2.90$ & $52.17 \pm 2.98$ & 0.35 & 0.732 \\
\hline $\begin{array}{c}\text { Control+ve } \\
\mathrm{N}=12\end{array}$ & $52.33 \pm 3.08$ & $53.00 \pm 2.80$ & 0.60 & 0.560 \\
\hline $\begin{array}{c}\text { Heat killed } \\
\mathrm{N}=12\end{array}$ & $69.08 \pm 0.67$ & $71.67 \pm 1.15$ & 7.22 & $0.001 * * *$ \\
\hline $\begin{array}{c}\text { Formalized } \\
\mathrm{N}=12\end{array}$ & $71.00 \pm 0.85$ & $75.42 \pm 0.90$ & 11.10 & $0.001 * * *$ \\
\hline
\end{tabular}

*extremely significant.

Data in each Colum represented the mean \pm standard deviation.

-ve control: fish only +ve control: fish injected with formalin. 
Use of vaccines in controlling bacteria fish diseases caused by Vibrio anuiliticus

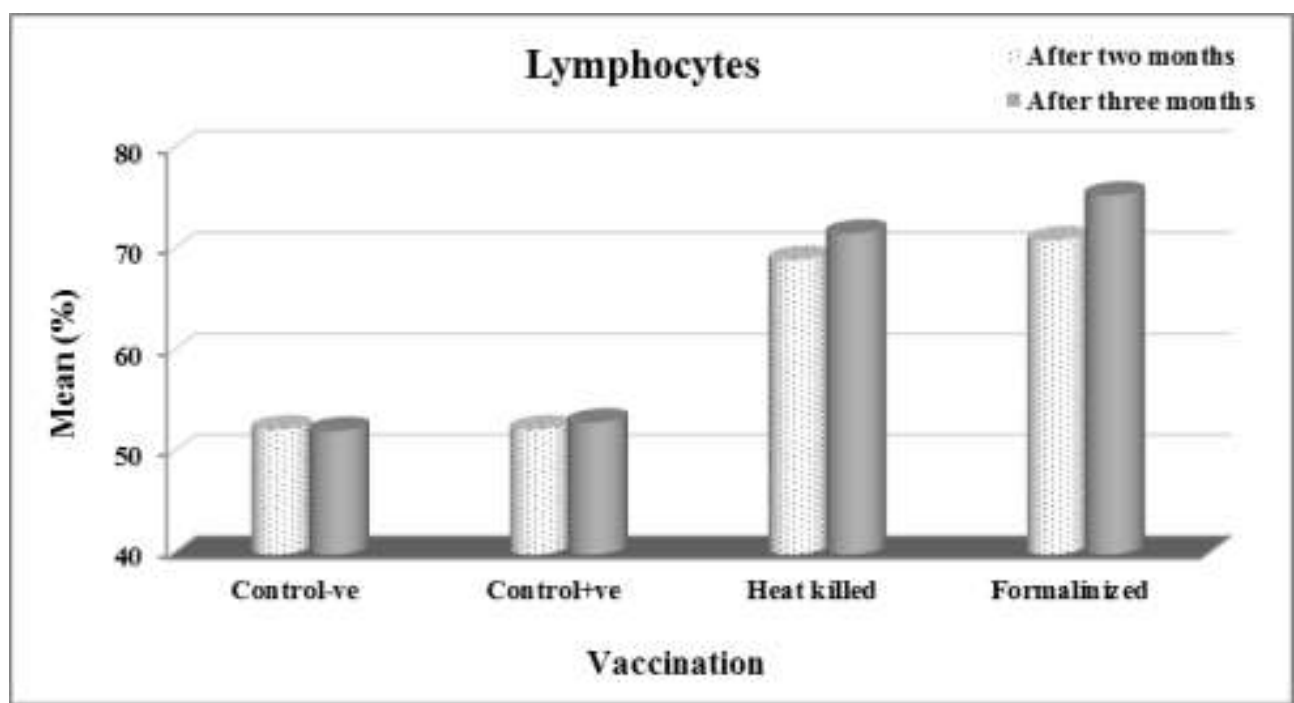

Fig. (7): Lymphocytes in vaccinated fish after two and three months of vaccination.

Table (8): Results of challenge test (Relative Level of Protection, RLP)) after two weeks.

\begin{tabular}{|c|c|c|c|c|}
\hline Group & $\begin{array}{c}\text { Total no. of } \\
\text { fish }\end{array}$ & Mortality & Mortality (\%) & R.L.P \\
\hline Control -ve & 20 & 10 & 50 & 16.66 \\
\hline Control +ve & 20 & 12 & 60 & 0.00 \\
\hline Heat killed & 20 & 2 & 10 & 83.33 \\
\hline Formalized & 20 & 1 & 5 & 91.66 \\
\hline
\end{tabular}

$\mathrm{RLP}=(1-$ mortalities of vaccinated fish/mortalities of control fish $) \times 100$

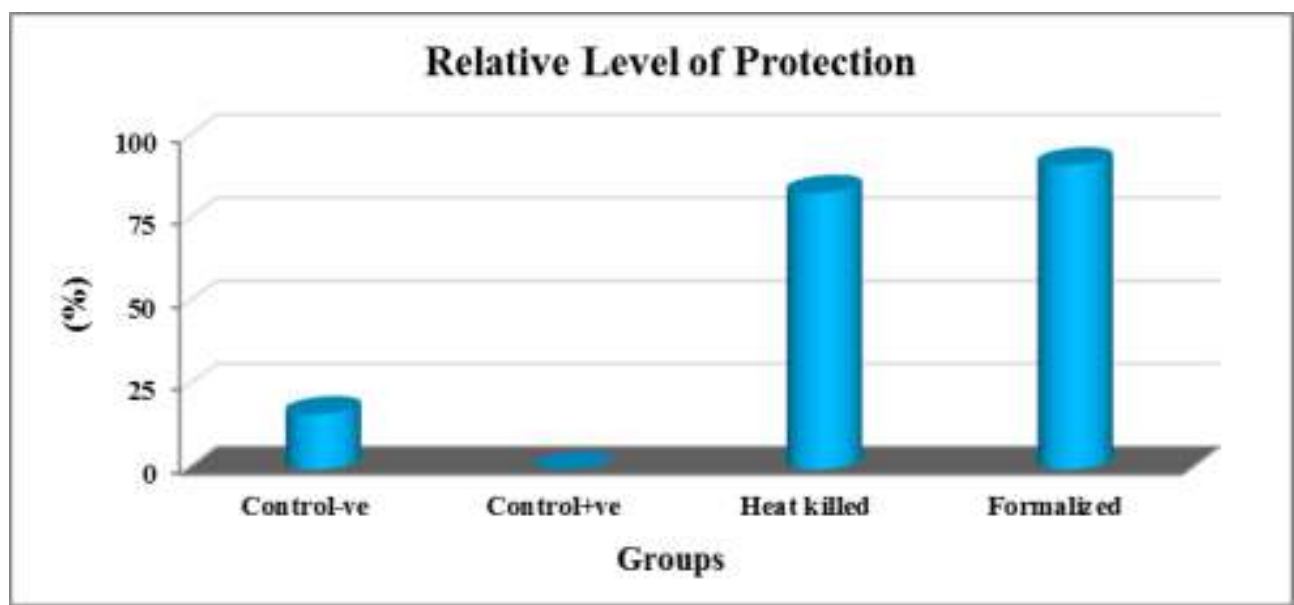

Fig. (8): Results of challenge test (Relative Level of Protection) after two weeks 


\section{Mohammed H. Bahnasawy et al.}

\section{REFERENCES}

Aly, S.M.; Tantawy, H.M.; Badran, A. and El-Baz, M.A. (2000). Histopathologic and Immunologic response of Clarias lazera to the injection of Aeromonas

hydrophila vaccine. Suez Canal Veter. Med. J., vol (1) 133-144.

Amend, D.F. (1981). Potency testing of fish vaccines. Developments in biological

Standardization, 49: 447-454.

Ardo, L.; Yin, G.; Xu, P.; Váradi, L.; Szigeti, G.; Jeney, Z. et al. (2008). Chinese herbs (Astragalus membranaceus and Lonicera japonica) and boron enhance the non-specific immune response of Nile tilapia (Oreochromis niloticus) and resistance against Aeromonas hydrophila Aquaculture, 275(1-4), 26-33.

Austin, B. and Austin, D.A. (1999). Bacterial fish pathogens, disease of farmed and wild fish, SpringerPraxis publishing in aquaculture and fisheries.

Bailone, R.L.; Martins, M.L.; Mouriño, J.L.; Vieira, F.N.; Pedrotti, F.S.; Nunes, G.C. and Silva BC.(2010). Hematology and agglutination titer after polyvalent immunization and subsequent challenge with Aeromonas hydrophila in Nile tilapia (Oreochromis niloticus). Arch Med. Veter., 42: 221-227

Barbosa, M.C.; A. Jatobá; F.d.N. Vieira; B.C. Silva; J.L.P. Mourino; E.R. Andreatta; W.Q. Seiffert and V.R. Cerqueira,( 2011). Cultivation of juvenile fat snook (Centropomus parallelus Poey, 1860) fed probiotic in laboratory conditions. Brazil. Arch. Biological Technology, 54(4): 795-801.
Bruno C. Silva; Mauricio L. Martins; Adolfo Jatobá; Celso C. Buglione Neto; Felipe N. Vieira; Gabriella V. Pereira; Gabriela T. Jerônimo; Walter Q. Seiffert; José Luiz P. Mouriño (2009). Hematological and immunological responses of Nile tilapia after polyvalent vaccine administration by different routes Pesq. Vet. Bras., 29(11): 874-880.

Buller, N.B. (2004). Bacterial from Fish and Other Aquatic Animals: A Practical Identification Manual. CABI Publishing, 166: 19-35.

Choi, S.H. and C.H. Oh (2007). Effect of oral immunization with liposomeentrapped bacterial antigen on protection against experimental Aeromonas hydrophila. Integrative Biosciences, 11: 33-38.

Colquhoun, A.J. and Lillehaug, A. (2014). Vaccination against Vibriosis. In: Gudding R., Lillehaug A., Evensen O., editors. Fish Vaccination. $1^{\text {st }}$ ed. John Wiley \& Sons, Ltd.; San Francisco, CA, USA. 172-184.

Conroy, D.A. and Herman, L.R. (1981). Text book of fish diseases. T.F.H. publ., West Sylvania

Díaz-Rosales, P.; Salinas, I.; Rodríguez, A.; Cuesta, A.; Chabrillón, M.; Balebona, M.C.; Moriñigo, M.A.; Esteban, M.A. and Meseguer, J.(2006). Gilthead sea bream Sparus aurata L. innate immune response after dietary administration of heat-inactivated potential probiotics. Fish Shellfish Immunology, 20:482-492.

Duncan, D.B. (1955). Multiple ranges and multiple F-tests. Biometrics. 11, 142.

Food and Agriculture Organization ,FAO (2016). The State of World Fisheries and Aquaculture; FAO: Rome, Italy.

Frans, I.; Michiels, C.W.; Bossier, P.; Willems, K.A. and Lievens, B. 


\section{Use of vaccines in controlling bacteria fish diseases caused by Vibrio anuiliticus}

(2011). Vibrio anguillarum as a fish pathogen: virulence factors, diagnosis and prevention. J. Fish Disease, 34:643-661.

Geng, X.; X.H. Dong; B.P. Tan; Q.H. Yang; S.Y. Chi; H.Y. Liu and X.Q. Liu (2012). Effects of dietary probiotic on the growth performance, non-specific immunity and disease resistance of cobia, Rachycentron canadum. Aquaculture Nutr., 18(1): 46-55.

Gudding, R. (2014). Vaccination as a preventive measure, in Fish Vaccination (eds R. Gudding A. Lillehaug and $\varnothing$. Evensen). Chichester, John Wiley \& Sons Ltd., 12-21.

Hay, F.C.; O.M.R. West Wood and P.N. Nelson. (2002). Practical immunology. Fourth edition. Blackwell, science. Great Britain by MPG Books Ltd, Bodmin, Corn Wall. 44, 71-100

Hu, Y.H.; Deng, T.; Sun, B.G.; Sun, L.(2012). Development and efficacy of an attenuated vibrio harveyi vaccine candidate with cross protective against vibrio alginoticus. Fish Shellfish Immunology, 32: 1155-1161.

Jun, L.; Siyuan, M. and Norman, Y.S.W. (2016). Vaccination of Silver Sea Bream (Sparus sarba) against Vibrio alginolyticus: Protective Evaluation of Different Vaccinating Modalities. International Journal Science. 17, $1-40$.

Kumaran, S.; Deivasigamani, B.; Alagappan, K. and Sakthivel, M. (2010). Infection and immunization trials of Asian sea bass (Lates calcarifer) against fish pathogen Vibrio anguillarum. J. Environ. Biol., 31: 539-541.

Li, J. and Woo, N.Y.S. (2003).
Pathogenicity of vibriosis in fish: an overview. J. Ocean Univ. China. 2:117-128.

Mancuso, M. (2014). Emerging bacterial diseases in Mediterranean Mariculture. J. Aquacult. Res., 1: 1-2.

Ouchterloney, O. (1962): Diffusion in gel methods for immunological analysis. In: Progress in allergy. 5, 30-154.

Oxoid. M. (1982). Oxoid manual $5^{\text {th }}$ Ed. Published by Oxoid Limited Hampshire, England.

Sajjad, D.; Moustafa, A. and Meysam, D. (2012). Efficacy of FormalinKilled, Heat -Killed ad Lipopolysaccharide Vaccines against Motile Aeromonads Infection in Rainbow Trout (Oncorhynchus mykiss). Global Veterinaria, 9(4):409-415.

Salah,.M.A.; $\quad$ Aqel,.S.A.;,Arshad,.H.R.; Nashwa.M.A. (2015): The response of New-Season Nile tilapia to Aeromnas hydrophila Vaccine. Int. J. Clin. Exper. Med., 8(3): 4508-4514

SAS (2000). Statistical analysis, SAS. STAT user guide version 6.2, SAS Instit. INC., Cary, NC.

Weicheselbaun, T.E. (1946).An accurate and rapid method for the determination of proteins in small amounts of blood serum and plasma. Am. J. Clin. Pathol.16, Tech. Sect., 10:40:49.

Whitman, K.A. (2004). Finfish and Shellfish Bacteriology Manual; Techniques and Procedures. Iowa State Press.

Woo, N.Y.S..and Kelly, S.P. (1995): Effects of salinity and nutritional status on growth and metabolism of Sparus sarba in a closed seawater system. Aquaculture. 135: 229238. 


\section{Mohammed H. Bahnasawy et al.}

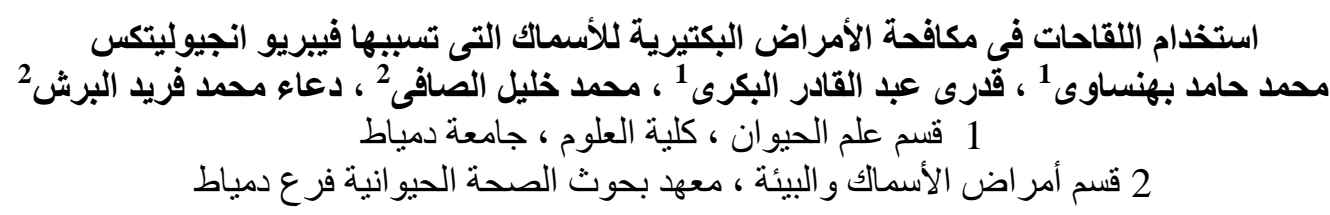

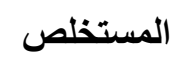

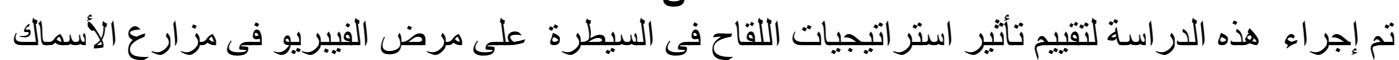

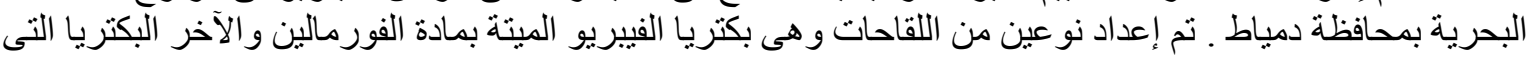

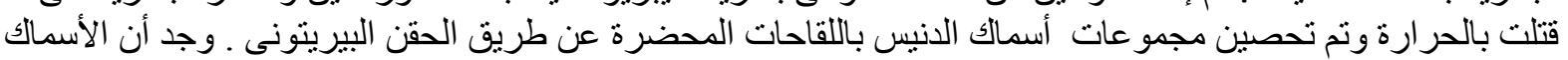

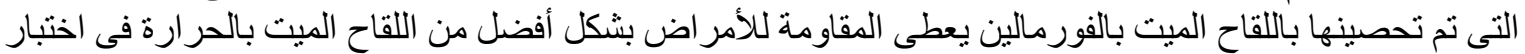

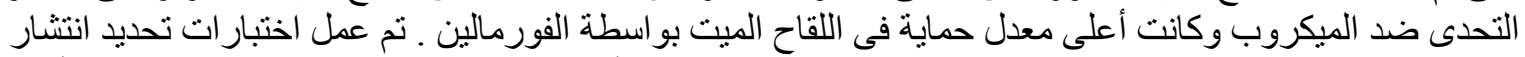

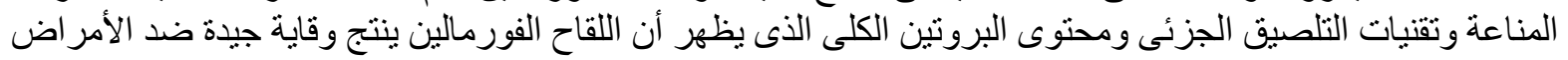
عن اللقاح الميت بالعرارة

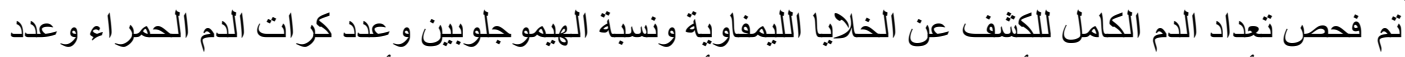

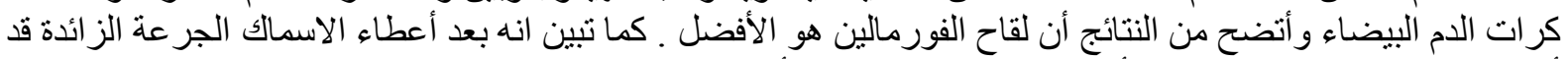

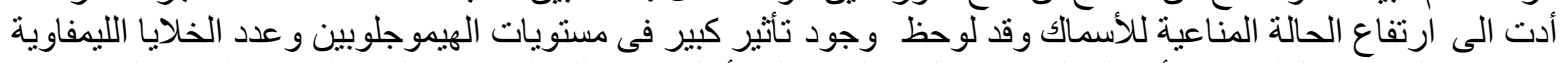
ومحتوى البروتين الكلى فى الأسماك المحصنة بلقاح الفورمالين أعلى من تلاكل المحصنة بلقاح البكتريا الميتهَ بالحر ارة. 